\title{
Partisipasi Orang Tua Siswa Dalam Menghadapi Pembelajaran Daring Di SD Kristen Elim Makassar
}

\section{Parents' Participation during Online Learning in SD Kristen Elim Makassar}

\author{
Nurwidyayanti ${ }^{1 *}$, Sundari Hmaid ${ }^{2}$, Syahriah Majid $^{2}$ \\ ${ }^{1}$ Sekolah Dasar Negeri SD Negeri 15 Lewang Kabupaten Wajo \\ ${ }^{2}$ Program Studi Pendidikan Dasar, Program Pascasarjana, Universitas Bosowa \\ *E-mail: yantinurwidya@gmail.com
}

Diterima: 11 September 2021/Disetujui 24 Desember 2021

\begin{abstract}
Abstrak. Penelitian ini bertujuan untuk mengetahui Partisipasi Orang Tua Siswa dalam Menghadapi Pembelajaran Daring dan kesulitan orang tua dalam pembelajaran daring di SD Kristen Elim Makassar. Penelitian ini merupakan penelitian kualitatif dengan menggunakan pendekatan deskriptif. Subjek dalam penelitian ini yaitu orang tua siswa dan guru wali kelas V. Pengumpulan data diambil melalui wawancara, observasi, dokumentasi. Penulis berperan sebagai pewawancara langsung untuk menggali data melalui orang tua siswa kelas V.Hasil penelitian menunjukkan bahwa peran orang tua dalam pembelajaran daring di SD Kristen Elim Makassar yaitu orang tua melaksanakan dua peran sekaligus pertama menjadi orang tua dan kedua menjadi guru di rumah; menyediakan sarana dan prasarana kepada anak; memberikan semangat; motivasi; mengarahkan anak sesuai dengan bakat dan minat yang dimiliki oleh masing-masing anak. Kesulitan orang tua dalam pembelajaran daring di SD Kristen Elim Makassar yaitu latar belakang pendidikan orang tua memengaruhi tingkat kemudahan dan kesulitan orang tua dalam mendidik anak; tingkat ekonomi orang tua memengaruhi proses pembelajaran secara daring terutama dalam hal memfasilitasi pembelajaran daring anak; kesulitan membagi waktu antara anak dan pekerjaan.
\end{abstract}

Kata Kunci: Partisipasi Orang Tua, Pembelajaran Daring.

\begin{abstract}
This research aims to know parent's participation in facing online learning and as well as to find out parental difficulties in online learning at Elim Christian Elementary School Makassar. This study is qualitative research and uses a descriptive approach. Subjects in this research are the student's parents and 5th grade homeroom. The data collection is taken through interviews, observation, and documentation. The writer acts as the interviewer to dig up data through the 5th grade student's parents. The results show that the role of parents in online learning at Elim Christian Elementary School Makassar carry out two roles. The first is being parents and the second is being a teacher at home, providing infrastructure, giving encouragement and motivation, and being a guide to students according to their interest and talents. The difficulties faced by parents at Elim Christian Elementary School Makassar are the educational background of parents affecting the level of ease and difficulty in dealing with children, the economic level of parents affecting the online learning process, especially in terms of facilitating children's learning, and the difficulty to manage their time for children and work.
\end{abstract}

Keywords: Parent's Participation, Online Learning.

This work is licensed under Creative Commons Attribution License 4.0 CC-BY International license

\section{Pendahuluan}

Pendidikan merupakan usaha sadar yang dilakukan oleh manusia agar dapat mengembangkan potensi dirinya melalui proses pembelajaran (Rahma et all, 2020). Pendidikan mengemban tugas untuk menghasilkan sumber daya manusia yang berkualitas bagi pembangunan bangsa dan negara. Selain itu, pendidikan juga berperan penting dalam rangka mengembangkan kehidupan manusia dan meningkatkan kemajuan suatu negara.

Tujuan pendidikan nasional akan dapat dicapai bila didukung oleh seluruh lapisan masyarakat. Upaya pemerintah dalam mewujudkan tercapainya tujuan pendidikan nasional yaitu dengan diselenggarakanya pendidikan melalui tiga jalur sebagaimana yang tertuang dalam UU No. 20 Tahun 2003 pasal 13 ayat (1) yang berbunyi: "jalur pendidikan terdiri atas pendidikan formal, non formal dan informal" (Depdiknas, 2003).

Pendidikan formal diselenggarakan dalam bentuk sekolah dan perguruan tinggi. Pendidikan non formal diselenggarakan di dalam masyarakat dalam bentuk kursus, edangkan pendidikan informal merupakan jalur pendidikan keluarga dan lingkungan. Pendidikan bisa diperoleh melalui lembaga- lembaga pendidikan formal, non formal dan informal mulai dari pendidikan dasar hingga perguruan tinggi. Lembaga pendidikan sesuai dengan fungsinya mempunyai peranan yang penting untuk mencetak atau melahirkan sumber daya manusia (SDM) yang berkualitas, sehingga mampu mengembangkan peranannya dalam pembangunan nasional. Lembaga pendidikan diharapkan mampu mengoptimalkan potensi yang dimiliki anak sehingga pada akhirnya dapat menghasilkan prestasi yang lebih baik (Triwiyanto, 2014)

Anak adalah manusia yang diamanatkan Allah SWT kepada manusia, dalam hal ini orang tua bertanggung jawab terhadap anak-anak mereka di hadapan Allah. Anak diciptakan oleh Allah SWT dengan dibekali potensi-potensi alamiah 
yang dapat diarahkan menuju kebaikan, atau sebaliknya (Muhammadiah \& Hamid, 2020) dan sudah menjadi kewajiban orang tua untuk memanfaatkan potensi-potensi alamiah tersebut dengan menyalurkannya ke jalan yang baik dengan membiasakan anak sejak dini untuk berbuat baik kepada sesama makhluk yang diciptakan Allah SWT dan adat istiadat yang baik agar anak dapat tumbuh dan berkembang menjadi manusia yang berakhlakul karimah (Rahmayani, 2019).

Keluarga merupakan lingkungan pendidikan yang pertama dan utama. Disebut sebagai lingkungan atau lembaga pendidikan pertama karena sebelum menusia mengenal lembaga pendidikan yang lain, justru lembaga pendidikan inilah yang pertama ada (Triwiyanti, 2014). Partisipasi orang tua sangat penting dalam perkembangan anak. Orang tua yang memberikan segalanya untuk kegiatan belajar anak di rumah akan berbanding terbalik dengan orang tua yang hanya menyerahkan anaknya di sekolah. Orang tua yang menyadari betapa pentingnya pendidikan bagi anaknya, akan turut serta dalam upaya pendidikan anaknya di rumah (Oualeng, et all, 2021). Orang tua akan senantiasa mendidik anaknya di rumah. Hal ini dikarenakan anak lebih banyak menghabiskan waktunya di rumah dibanding di sekolah. Partisipasi orang tua sangat penting dalam menentukan keberhasilan pendidikan anak-anak mereka. Induk partisipasi dan tanggung jawab antara lain dapat diwujudkan dengan membimbing kelangsungan anak belajar di rumah sesuai dengan program yang telah dipelajari oleh anak-anak di sekolah belajar (Sukmadinata, 2009).

Indonesia dengan beberapa pertimbangan menerapkan kebijakan WFH (Work From Home) dan Social Distancing (pembatasan jarak sosial) salah satunya dengan kebijakan pembelajaran daring (dalam jaringan). Kebijakan ini tentu membuat perubahan besar dalam pelaksanaan dunia pendidikan anak, dimana orang tua berperan penting untuk pembelajar dirumah. Hal ini dikarenakan karena pembelajaran dilakukan di rumah tanpa kehadiran sosok guru dan teman belajar. Dengan adanya keadaan tersebut orang tua diharuskan melakukan peran lebih karena orang tua merupakan penanggung jawab utama terhadap pendidikan anak-anaknya (Muhammadiah \& Hamid, 2020) Baik dilembaga formal, informal, maupun non-formal. Orang tua berperan dalam menentukan keberhasilan pendidikan anak-anak. Diantara induk- induk peran dan tanggung jawab antara lain membimbing kelangsungan belajar dirumah dengan mengawasi dan membantu pengaturan tugas sekolah (Umar, 2015).

Melihat kasus pandemi akibat virus corona (Covid-19). Pemerintah telah mengalihkan kegiatan pembelajaran dari sekolah ke rumah masing- masing siswa sebagai bagian dari upaya menghentikan penyebaran virus corona (Covid-19). Agar tidak disalah artikan sebagai hari libur, maka proses kegiatan pembelajaran dilakukan secara online. Penggunaan media pembelajaran dalam proses belajar mengajar merupakan salah satu upaya untuk meningkatkan efektivitas serta kualitas proses pembelajaran yang pada akhirnya dapat meningkatkan kualitas hasil belajar siswa. Penggunaan media pembelajaran daring (online) sebagai media distance learning (pembelajaran jarak jauh) menciptakan paradigma baru apabila dibandingkan dengan pendidikan konvensional (Dewi, 2011).

Pembelajaran daring bertujuan memberikan layanan pembelajaran bermutu dalam jaringan (daring) yang bersifat masif dan terbuka untuk menjangkau peminat yang lebih banyak dan lebih luas (Sofyana, 2019: 82). Kegiatan belajar dari rumah diselenggarakan secara daring (dalam jaringan), kegiatan belajar anak tersebut dilaksanakan di rumah dan menjadi tanggung jawab orang tua. Partisipasi belajar dari rumah ini dapat dilihat dari bagaimana orang tua dalam membimbing anak selama pembelajaran daring (Rahyuni, 2021).

Tugas diberikan guru sesuai jadwal mata pelajaran dan jam pelajaran, peserta didik kemudian mengerjakan secara mandiri rumah. Namun yang pasti harus dilakukan adalah pemberian tugas melalui pemantauan dan pendampingan oleh guru, sehingga anak benar-benar belajar. Adanya pembelajaran daring menambah tugas orang tua yang juga menjadi guru di rumah. Dengan keterlibatan orang tua menjadi alternatif yang dapat digunakan untuk meningkatkan kerjasama pendidik dan orang tua serta meningkatkan partisipasi orang tua.

Permasalahan yang terjadi banyak orang tua siswa yang mengeluhkan proses pembelajaran online. Selama ini orang tua memberikan tanggung jawab pendidikan anaknya kepada guru sekolah. Dikarenakan melihat kondisi sekarang orang tua memiliki partisipasi ganda dalam proses pembelajaran daring di rumah. Selain tanggung jawab mendidik anak, orang tua dituntut mendampingi anak belajar daring di rumah sebagai ganti pembelajaran yang dilakukan di kelas/sekolah. Dalam kondisi seperti saat ini, disadari atau tidak, para orang tua menjalankan partisipasi ganda pendidikan.

Partisipasi utama orang tua. Secara universal, para orang tua dituntut memikirkan dan merealisasikan pendidikan terbaik bagi anak-anak mereka. Kewajiban ini melekat pada setiap orang tua. Sebab hadirnya buah hati adalah sebagai penerus dan masa depan keluarga dan juga peradaban sebuah bangsa. Maka jelaslah orang tua harus memastikan, melalui teladan, anaknya menjadi baik dari sisi kepribadian, keilmuan dan juga masa depan. Partisipasi tambahan orang tua. Partisipasi tambahan ini muncul seiring pembatasan sosial. Belajar di rumah menjadi solusi yang tak terelakkan.

Penelitian tentang partisipasi orang tua dalam menciptakan pemanfaatan internet untuk pendidikan masih sangat jarang dilakukan. Begitupun bagaimana partisipasi orang tua dan guru dalam membangun kebiasaan anak untuk memanfaatkan internet untuk pembelajaran masih belum dilakukan. Partisipasi orang tua dan guru ini sangat penting, karena mereka adalah orang yang berhadapan langsung dengan anak-anak dilingkungan keluarga dan sekolah. Kondisi tersebut menarik peneliti untuk melakukan penelitian ini

\section{Metode Penelitian}

Jenis penelitian yang digunakan adalah deskriptif. Penelitian deskriptif sebagaimana yang diungkapkan Sugiyono (2012), penelitian kualitatif sebagai metode penelitian yang berlandaskan pada filsafat postpositivisme, digunakan untuk meneliti pada kondisi objek alamiah, dimana peneliti adalah sebagai instrumen kunci, teknik pengumpulan data dengan triangulasi, analisis data bersifat induktif atau kualitatif, dan hasil penelitian kualitatif lebih menekankan makna dari pada generalisasi. 
Penelitian kualitatif yaitu rangkaian kegiatan untuk memperoleh data yang bersifat apa adanya tanpa ada dalam kondisi tertentu yang hasilnya lebih menekankan makna. Di sini, peneliti menggunakan metode penelitian deskriptif dengan mengolah data yang diperoleh dari wawancara dan dokumentasi dengan mendeskripsikannya untuk mendapat gambaran tentang partsipasi orang tua siswa dalam menghadapi pembelajaran daring.

Lokasi penelitian di SD Kristen Elim Makassar. Penulis memilih penelitian di SD Kristen Elim Makassar karena sekolah ini sudah menerapan pembelajaran daring berupa pembelajaran yang menggunakan aplikasi zoom yang mana partisipasi orang tua sangatlah penting dalam proses belajar anak. Penelitian ini dilakukan pada 4 Maret 2021. Fokus penelitian penelitian ini adalah partisipasi orang tua siswa dalam menghadapi pembelajaran daring

Teknik pengumpulan data yang digunakan dalam penelitian ini meliputi:

Wawancara dan dokumentasi dalam penelitian ini merupakan sebagai pelengkap data penelitian yakni untuk mendapatkan data tertulis berupa data yang didalamnya memuat gambaran umum sekolah seperti keadaan sekolah, visi dan misi, kondisi guru dan siswa, sarana dan prasarana, partisipasi guru mengajar serta data-data yang menggambarkan partisipasi orang tua dalam pembelajaran daring di rumah.

Teknik analisis data yang digunakan dalam penelitian ini adalah analisa interaktif yang mulai dari pengumpulan data, reduksi data, penyajian data dan penarikan kesimpulan. Menurut Afifudin (2012:159), yaitu sebagai berikut:

1. Pengumpulan Data (Data Collection)

Pengumpulan data merupakan unsur integral dari kegiatan analisis data. Aktifitas pengumpulan data pada penelitian ini ialah dengan menggunakan wawancara dan studi dokumentasi.

2. Reduksi Data (Data Reduction)

Reduksi data adalah sebuah proses pemilihan, pemusatan perhatian pada penyederhanaan dan transformasi data yang kurang jelas yang muncul dari catatan-catatan tertulis di lapangan. Reduksi dilakukan dimulai dari pengumpulan data dengan membuat ringkasan, mengkode, menelusur tema, membuat gugus-gugus, menulis memo dan sebagainya dengan tujuan menghilangkan data/informasi yang tidak relevan.

3. Display Data

Display data ialah sebuah penjelasan sekumpulan informasi tersusun yang memberikan kemungkinan adanya penarikan kesimpulan dan pengambilan tindakan. Penyajian data kualitatif disajikan dalam bentuk teks naratif. Penyajiannya dapat berupa matrik, diagram, tabel dan bagan.

4. Verifikasi dan Penegasan Kesimpulan (Conclution Drawing and Verification)

Merupakan kegiatan akhir dari analisis data. Pengambilan kesimpulan berupa kegiatan interpretasi, adalah mendapatkan makna data yang telah disajikan. Antara display data dan pengambilan kesimpulan terdapat aktivitas analisis data yang ada. Dalam pengertian ini analisis data kualitatif merupakan usaha berlanjut, berulang dan terusmenerus. Masalah reduksi data, penyajian data dan penarikan kesimpulan/ verifikasi menjadi gambaran keberhasilan secara berurutan sebagai rangkaian kegiatan analisis yang terkait.

Berikutnya data yang sudah dianalisis, dijelaskan dan dimaknai dalam bentuk kata-kata untuk mengambarkan fakta yang ada di lapangan, pengambaran, atau untuk menjawab pertanyaan penelitian yang selanjutnya diambil intisarinya. Berdasarkan keterangan di atas, maka setiap tahap dalam proses tersebut dilakukan untuk mendapatkan keabsahan data dengan menelaah seluruh data yang ada dari berbagai sumber yang telah didapat dari lapangan dan dokumen pribadi, dokumen resmi, gambar, foto dan sebagainya melalui metode wawancara.

\section{Hasil dan Pembahasan}

Proses pembelajarann daring menjadikan Orang tua berpartisipasi sebagai guru, pendamping anak dirumah sedangkan guru profesional dengan tugas utama adalah mendidik, mengajar, membimbing, mengarahkan, melatih, menilai, dan mengevaluasi peserta didik (Puspita et al., 2021). Maksud dari orang tua berpartisipasi sebagai guru merupakan sebuah kegiatan yang dilakukan oleh seseorang dalam rangka memberikan bantuan kepada orang lain yang mengalami kesulitan, sehingga orang tersebut mampu mengatasi sendiri dengan penuh kesadaran. Kegiatan pendidikan maupun pembimbingan yang diberikan orang tua terhadap anak dilakukan dari anak usia lahir sampai dewasa, baik pemberian pelajaran hidup, agama, maupun pembelajaran umum (Imron, 2016).

Hasil penelitian yang dilakukan di SD Kristen Elim Makassar, peneliti dapat menyimpulkan dari setiap hasil wawancara, observasi maupun dokumentasi mengenai partisipasi orang tua dalam pembelajaran daring adalah orang tua mengeluhkan masalah waktu karena orang tua banyak yang bekerja sebagai ibu rumah tangga pada saat jam pembelajaran sehingga waktu yang dimiliki sangat terbatas untuk mendamping anaknya, orang tua yang bekerja di luar rumah cenderung lebih sulit berpartisipasi dalam membantu anak untuk belajar dibandingkan dengan orang tua yang tinggal di rumah, dan dalam segi kesulitan ada orang tua yang sulit mengajari anak mereka karena mereka juga tidak mengetahui pembelajaran atau materi yang diberikan oleh guru di SD Kristen Elim Makassar, dan beberapa orang tua sudah mengetahui partisipasi mereka sebagai orang tua dalam menyongsong keberhasilan pendidikan anak-anak mereka.

Orang tua berpartisipasi penting dalam menyongsong keberhasilan pendidikan anak-anak mereka, terutama selama pembelajaran daring, partisipasi orang tua sangat dibutuhkan seperti mengajari anak belajar dan mendampingi anak belajar, memberikan suasana nyaman supaya anak fokus belajar, memberi dorongan kepada anak supaya anak mau belajar, memberikan fasilitas untuk belajar, mengarahkan anak sesuai dengan bakat dan minat yang dimiliki oleh masing-masing anak. 
Hasil deskripsi data sebelumnya juga sudah menunjukkan bahwa partisipasi orang tua dalam pembelajaran daring meliputi: a) partisipasi orang tua sebagai guru; b) partisipasi orang tua sebagai fasilitator; c) partisipasi orang tua sebagai motivator; d) partisipasi orang tua sebagai pengaruh atau director. Hasil penelitian ini sesuai dengan penelitian Heriyani (2010) dalam membimbing belajar anak orang tua dapat berpartisipasi sebagai pendidik, pelindung, motivator, fasilitator, dan pembimbing. Adapun faktor pendukung dan penghambat dari belajar siswa kelas IV MI Ma arif Bajarparakan Kecamatan Rawalo Kabupaten Banyumas. Hasil penelitian ini sesuai dengan penelitian yang dilakukan Nika Cahyati (2020) partisipasi orang tua sangat diperlukan untuk proses pembelajaran anak selama study from home ini, partisipasi orang tua juga sangat diperlukan untuk memberikan edukasi kepada anak- anaknya yang masih belum bisa memahami tentang pandemi yang sedang mewabah untuk tetap berdiam diri dirumah agar tidak tertular dan menularkan wabah pandemi ini. Orang tua merasa pembelajaran di rumah sangat efektif untuk diterapkan namun bukan berarti pembelajaran di sekolah tidak lebih efektif dibandingkan dengan kegiatan pembelajaran di rumah.

Hasil penelitian di SD Kristen Elim Makassar, peneliti dapat menyimpulkan dari setiap hasil wawancara, observasi maupun dokumentasi mengenai kesulitan yang dihadapi orang tua dalam pembelajaran daring di SD Kristen Elim Makassar Tahun Pelajaran 2020/2021 beberapa orang tua mengalami kesulitan yang serupa dalam pembelajaran daring.

Kesulitan yang dihadapi orang tua dalam pembelajaran daring seperti kurangnya siswa dalam memahami materi yang diterima pada saat pembelajaran daring sehingga mengharuskan orang tua untuk mempelajari materi yang bukan bidangnya, orang tua sulit membagi waktu meraka.

Hasil deskripsi data sebelumnya juga sudah menunjukkan bahwa kesulitan yang dihadapi orang tua dalam pembelajaran daring meliputi: a) latar belakang pendidikan orang tua; b) waktu yang tersedia. Hasil penelitian ini sesuai penelitian yang dilakukan Anita Wardani (2020) kendala-kendala orang tua dalam mendampingi anak belajar di rumah pada masa pandemi Covid-19 adalah kurangnya pemahaman materi oleh orang tua, kesulitan orang tua dalam menumbuhkan minat belajar anak, tidak memiliki cukup waktu untuk mendampingi anak karena harus bekerja, orang tua tidak sabar dalam mendampingi anak saat belajar dirumah, kesulitan orang tua dalam mengoperasikan gadget, dan kendala terkait jangkauan layanan internet. Penelitian ini juga sesuai oleh penelitian yang dilakukan Eka Selviana (2020) kendala yang dihadapi orang tua yaitu: 1. Mengatur emosional anak, 2. Minimnya tingkat pemahaman orang tua.

\section{Kesimpulan dan Saran}

Partisipasi Orang Tua dalam Pembelajaran Daring di SD Kristen Elim Makassar Tahun Pelajaran 2020/2021 berbeda jika dibandingkan dengan pembelajaran konvensional. Orang tua melaksanakan dua partisipasi sekaligus pertama menjadi orang tua dan kedua menjadi guru di rumah; menyediakan sarana dan prasarana kepada anak; memberikan semangat; motivasi; mengarahkan anak sesuai dengan bakat dan minat yang dimiliki oleh masing-masing anak. Kesulitan yang Dihadapi Orang Tua dalam Pembelajaran Daring di SD Kristen Elim Makassar Tahun Pelajaran 2020/2021 yaitu latar belakang pendidikan orang tua memengaruhi tingkat kemudahan dan kesulitan orang tua dalam mendidik anak; kesulitan membagi waktu antara anak dan pekerjaan, maka ada beberapa saran yang akan penulis sampaikan, yaitu: Orang tua diharapkan dapat membimbing anak sesuai kebutuhan anak dalam pembelajaran daring, Orang tua diharapkan dapat menyediakan fasilitas penuh dalam pelaksanaan pembelajaran daring, Orang tua diharapkan dapat menyediakan waktu untuk memberikan pendampingan serta bimbingan kepada anak, Orang tua diharapkan dapat memberikan semangat serta motivasi kepada anak agar tetap dapat melaksanakan pembelajaran daring sesuai dengan tujuan pembelajaran yang diinginkan. Guru kelas diharapkan dapat memantau serta dapat melakukan kerja sama bersama orang tua dengan baik. Sehingga tujuan dalam pembelajaran dapat tercapai meskipun dilaksanakan secara daring dan Siswa diharapkan memiliki semangat dan mampu mengikuti pembelajaran daring dengan baik agar tetap dapat mencapai hasil belajar yang maksimal.

\section{Daftar Pustaka}

Arikunto, Suharsimi. 2006. Prosedur Penelitian Suatu Pendekatan Praktik. Jakarta: Rineka Cipta.

Dewi, Shinta Kurnia. 2011. Efektivitas E-Learning Sebagai Media Pembelajaran Mata Pelajaran TIK Kelas XI di SMA Negeri 1 Depok. Yogyakarta: Jurusan Pendidikan Teknik Informatika Universitas Negeri Yogyakarta.

Depdiknas. (2003). Undang-undang RI No.20 tahun 2003 tentang Sistem Pendidikan Nasional. Diunduh dari https://kelembagaan.ristekdikti.go.id/wpcontent/uploads/2016/08/UU_no_20_th_2003.pdf pada 22 Juli 2019

Heryani, \& Reni. (2010). Buku asuhan kebidanan ibu nifas dan menyusui. Jakarta: TIM

Oualeng, H., Muhammadiah, M., \& Hamid, S. (2021). Peran Orang Tua Dan Wali Kelas Dalam Pembentukan Afektif Siswa Di Sd Negeri Nusa Harapan Permai Kota Makassar. Bosowa Journal of Education, 1(2), 76-80. https://doi.org/10.35965/bje.v1i2.658

Rahmayani, Ayu. 2019. Pengaruh Intensitas Komunikasi Terbuka Orang Tua Dengan Anak Terhadap Prestasi Belajar Mata Pelajaran Pendidikan Agama Islam (PAI) Peserta Didik Kelas Xi Sma Negeri 02 Brebes. Semarang: Jurusan Pendidikan Agama Islam UIN Walisongo Semarang.

Rahmah, R., \& Hamid, S. (2020). Pola Asuh Orangtua Terhadap Dorongan Aktivitas Belajar dan Hasil Belajar Siswa Sekolah Dasar Di Kabupaten Maros. Bosowa Journal of Education, 1(1), 1-4.

Rahyuni, R., Yunus, M., \& Hamid, S. (2021). Pengaruh Game Online Terhadap Motivasi Belajar dan Prestasi Belajar Siswa SD Kecamatan Pammana Kabupaten Wajo. Bosowa Journal of Education, 1(2),65-70. https://doi.org/10.35965/bje. v1i2. 657

Sofyana, Latjuba dkk. 2019. Pembelajaran Daring Kombinasi Berbasis Whatsapp Pada Kelas Karyawan Prodi Teknik Informatika Universitas Pgri Madiun. Jurnal Nasional Pendidik, 8(1). 
Sugiyono. 2012. Metode Penelitian Kuantitatif, Kualitatif dan R\&D. Bandung: Alfabeta.

Sukmadinata, Nana Syaodih. 2009. Landasan Psikologi Proses

Triwiyanto Teguh.Pengantar Pendidikan,(2017) Jakarta. Bumi Aksara

Umar, M. (2015). Peranan Orang Tua Dalam Peningatan Prestasi Belajar Anak. Jurnal Ilmiah Edukasi, 20-28.

Undang-undang Republik Indonesia No 20 Tahun 2003. Pendidikan.Bandung: PT Rosdakarya. 